\title{
@๑@ఠ Ipseidade e alteridade nas obras sobre educação do jovem Nietzsche
}

\author{
Fernando de Sá Moreira*
}

\begin{abstract}
Resumo: O presente artigo propõe uma interpretação do tema da identidade pessoal nos escritos sobre educação do jovem Nietzsche. A reflexão nietzschiana sobre a educação é perpassada pelo conceito de si-mesmo e sua contraparte, o outro. Cada um desses conceitos desempenha papéis importantes na formação do indivíduo e possuem duas subdivisões básicas: o outro fora do indivíduo, o outro no interior do indivíduo, o si-mesmo no interior do indivíduo e o si-mesmo acima do indivíduo. O resultado é um si-mesmo mutável, mas não completamente sujeito à educação, e uma alteridade como ferramenta para o fortalecimento de identidades do indivíduo.
\end{abstract}

Palavras-chaves: Si-mesmo. Ipseidade. Alteridade. Educação. Autenticidade.

\section{Ipseity and otherness in the works on the education of the young Nietzsche}

Abstract: This paper proposes an interpretation of the theme personal identity in the writings on the education of the young Nietzsche. Nietzsche's thought on education is permeated by the concept of self and its counterpart, the other. Each of these concepts plays important roles in the formation of the individual and have two basic subdivisions: the other outside the individual, the other inside the individual, the self inside the individual and the self above the individual. The result is a mutable self, but not completely susceptible to education, and an otherness as tool, with which the individual strengths its own identity.

Keywords: Self. Ipseity. Otherness. Education. Authenticity.

\footnotetext{
${ }^{*}$ Doutor em filosofia pela Pontifícia Universidade Católica do Paraná (PUC-PR). Professor de História e Filosofia da Educação no Curso de Licenciatura em Física e Professor de Filosofia em Cursos de Ensino Médio integrados ao Ensino Técnico do Instituto Federal do Paraná (IFPR). E-mail: urbanoia@gmail.com
} 


\section{Selbstigkeit und Andersheit in den Werken über Erziehung vom jungen Nietzsche}

Zusammenfassung: Dieser Aufsatz legt eine Interpretation für das Thema persönliche Identität in den Werken über Erziehung und Bildung vom jungen Nietzsche dar. Nietzsches Gedanken über solches Thema ist reich an Überlegungen über den Begriff „Selbst“ und sein Gegenstück, d. h. „,das Andere“. Jede dieser Begriffe spiele wichtige Rollen für die Bildung des Einzelnen und habe zwei grundsätzliche Unterteilungen: das außerhalb des Einzelnen liegende Andere, das innerhalb des Einzelnen liegende Andere, das innerhalb des Einzelnen liegende Selbst und das über den Einzelnen liegende Selbst. Das Ergebnis sei zwar ein veränderliches Selbst, aber kein völlig durch Erziehung veränderliches Selbst, und eine Andersheit, die als Werkzeug zum Stärkung der einzelnen Identitäten dienen könne.

Schlüsselwörter: Selbst. Selbstigkeit. Andersheit. Erziehung. Authentizität.

\section{Introdução}

O objetivo do presente artigo é argumentar em defesa da seguinte hipótese: a reflexão nietzschiana sobre a educação seria perpassada pelo conceito de si-mesmo (Selbst) ${ }^{1}$, isto é, articular-se-ia por meio de uma determinada noção de identidade pessoal, e, no entanto, tal conceito não poderia ser completamente entendido fora das relações que possui com as alteridades que o cercam. O processo educativo seria então um complexo transcurso de encontro e transformação de si

\footnotetext{
${ }^{1} \mathrm{O}$ conceito de si-mesmo dialoga em alguma medida com os conceitos de caráter da tradição alemã, em especial Immanuel Kant e Arthur Schopenhauer. Entre os intérpretes que também fazem essa aproximação encontram-se por exemplo Giacoia Jr. (2004 e 2012) e Salaquarda (cf. BROESE, KOSSLER, SALAQUARDA, pp. 253-265). O termo alemão selbst ou selber equivale aos termos portugueses "mesmo" e "próprio" em expressões como "eu mesmo" ("ich selbst"), "o próprio Nietzsche" ("Nietzsche selbst") etc. Como prefixo de um substantivo equivale a "auto-" (e.g. Selbsterhaltung, autoconservação, conservação de si). O uso substantivado "das Selbst" pode ser traduzido como "o si-mesmo", "a ipseidade", "o ser próprio".
} 
mesmo, o qual ora seguiria o outro, ora se desviaria do outro para ocorrer. Ipseidade e alteridade seriam portanto fundamentais para compreender o que significa o imperativo "sei du selbst!" ("seja você mesmo!") de Schopenhauer como educador (SE/Co. Ext. III 1, KSA 1, p. 338$)^{2}$

É de amplo conhecimento que Nietzsche foi um filósofo da individualidade. Grande parte de seus escritos, assim como parte significativa de seu pensamento é dedicado a percorrer os labirínticos caminhos que levam à identidade própria. Sua produção é atravessada por essa problemática, o que parece fornecer elementos para pensar a partir dele em uma ética da autenticidade. ${ }^{3}$ No entanto, como também é sabido, ele é simultaneamente um pensador da cultura e da educação.

\footnotetext{
${ }^{2}$ As referências aos textos de Nietzsche e de Schopenhauer seguem as convenções de siglas estabelecidas pelas revistas especializadas Cadernos Nietzsche e Revista Voluntas. No caso dos textos de Nietzsche são usadas as seguintes siglas: GT/NT para $O$ nascimento da tragédia; BA/EE para Sobre o futuro de nossos estabelecimentos de ensino; WL/VM para Sobre verdade e mentira no sentido extramoral; DS/Co. Ext. I para Considerações extemporâneas I - David Strauss: o devoto e o escritor; HL/Co. Ext. II para Considerações extemporâneas II - Da utilidade e desvantagem da história para a vida; SE/Co. Ext. III para Considerações extemporâneas III - Schopenhauer como educador; WB/Co. Ext. IV para Considerações extemporâneas IV - Richard Wagner em Bayreuth; MAI/HHI para Humano, demasiado humano; M/A para Aurora; EH/EH para Ecce homo; KSA para Kritische Studienausgabe; BVN/CN para as cartas de Nietzsche disponibilizadas na Digitale Kritische Gesamtausgabe von Nietzsches Werken und Briefen (eKGWB) organizada por Paolo D'Iorio; CV/CP para Cinco prefácios para cinco livros não escritos; NF/FP, seguido do ano e número da anotação, para os fragmentos póstumos, segundo a organização da KSA. No caso dos textos de Schopenhauer: N/N para Sobre a vontade na natureza; WWV I/MVR I para $O$ mundo como vontade e representação, tomo I; WWV II/MVR II para $O$ mundo como vontade e representação, tomo II; M/M para Sobre o fundamento da moral; P/P para Parerga e Paralipomena; Zürcher para Zürcher Ausgabe. Todas as traduções são de minha responsabilidade, embora eu as tenha cotejado e consultado as traduções já existentes indicadas na bibliografia. Sempre que possível, foi realizada a vinculação eletrônica das menções à obra de Nietzsche com as respectivas passagens na eKGWB para facilitar a consulta ao material original.

${ }^{3}$ Ainda que seja um ferrenho crítico da moral, vários intérpretes do pensamento nietzschiano encontram em seus escritos apontamentos que poderiam em algum sentido ser descritos como éticos (e.g. AZEREDO, 2008; DIAS, 2011, p. 140; LAROSSA, 2009, p. 34; MACHADO, 2002, p. 61). A diferença de uma ética nietzschiana e daquela que é alvo de sua crítica à moral seria principalmente o fato de que a reflexão de Nietzsche não seria prescritiva, tampouco universalizável.
} 
Ora, considerando que a cultura e a educação são fundamentalmente construídas no encontros de vários atores e circunstâncias, seria estranho desconsiderar que também a figura do outro é importante em sua filosofia. Portanto, não deveria ser nenhuma surpresa que partes importantes do debate nietzschiano sobre a Bildung (formação, educação, cultura) sejam permeadas pela tensa e difícil relação entre o si-mesmo (Selbst) e o outro, entre ipseidade e alteridade, tal como tento evidenciar no decorrer deste trabalho.

O tema é amplo e por isso é preciso fazer algumas limitações. Quanto ao material de trabalho, deve-se considerar que o envolvimento de Nietzsche com a educação pode ser abordado a partir de ao menos quatro materiais de pesquisa, que podem dialogar entre si.

1. Suas reflexões publicadas ou póstumas sobre a educação como processo institucionalizado; ou seja, sobre os estabelecimentos de ensino, a profissão de professor, a condição do corpo estudantil nos institutos de educação etc;

2. Suas reflexões publicadas ou póstumas sobre a educação em sentido mais amplo; ou seja, independentemente dos estabelecimentos formais de educação. Pode-se pensar neste caso na questão da autoformação, a esfera da cultura, as preocupações com a linguagem etc;

3. Os registros biográficos de Nietzsche nos estabelecimentos de ensino; isto é, sua experiência como um frequentador de espaços institucionais de educação e como profissional da educação, primeiramente na condição de estudante (e.g. em Schulpforta, Bonn e Leipzig), posteriormente na condição de professor (e.g. no Pädagogium e na Universidade da Basileia). Pode-se pensar aqui também nos relatos e impressões que outras pessoas tiveram dessas experiências, como por exemplo seus ex-alunos, colegas de trabalho, amigos etc;

4. Os registros biográficos de Nietzsche fora dos estabelecimentos de ensino; isto é, sua experiência enquanto alguém que acumula em si 
experiências docentes, mas que não atua mais profissionalmente enquanto tal. Nesse caso, poder-se-ia pensar sobre a influência da vida universitária para suas vivências errantes e também para suas diversas produções desde que se afastou das atividades na Basileia em 1879 até seu colapso intelectual nos primeiros dias de 1889 .

Como se pode facilmente perceber, uma pesquisa que tenha como objetivo desdobrar e articular todas esses materiais seria uma tarefa bastante delicada e extensa. Com efeito, o objeto do presente estudo é mais modesto. Sua atenção repousa essencialmente sobre os dois primeiros pontos, isto é, as reflexões escritas de Nietzsche sobre a educação, institucionalizada ou não. Tampouco é a intenção deste trabalho analisar toda a obra escrita de Nietzsche; o centro do debate gira essencialmente em torno dos escritos do filósofo alemão anteriores a Humano, demasiado humano (1878), naquele que é conhecido como seu primeiro período e que compreende sua produção filosófica entre 1869 e 1876/1877 aproximadamente. ${ }^{4}$

Diferente de pensadores como Platão, Comenius ou Rousseau, Nietzsche não possui uma obra de referência sobre o tema da educação. Em outras palavras, em seus escritos não se encontra um livro que reúna sistematicamente toda uma concepção pedagógica de modo aproximadamente acabado, tal como a República, a Didática magna ou o Emílio. A discussão se espalha por diversos de seus escritos de modo relativamente assistemático e fragmentário. Se se tomar a temática educacional em sentido amplo, é possível encontrar rastros dela em praticamente todos os períodos de produção intelectual de Nietzsche, talvez até mesmo em cada um de seus livros. Em um sentido mais estrito, a educação aparece como temática mais central e óbvia em ao menos dois textos: Sobre o futuro de nossos estabelecimentos de ensino e Schopenhauer como educador. A atenção do presente artigo dará

\footnotetext{
${ }^{4}$ Trata-se de um período marcado por uma intensa produção intelectual, articulado com uma igualmente intensa atividade docente e pontuado pelas famosas crises de saúde que, entre outras coisas, afetava fortemente a visão de Nietzsche (cf. KSA 15).
} 
maior foco a estes dois escritos, sem ignorar, é claro, as demais produções do período. Em função disso, os dois textos merecem uma breve contextualização.

Sobre o futuro de nossos estabelecimentos de ensino é um material inacabado e não publicado por seu autor em vida. Como o próprio nome indica, a obra se debruça mais longamente sobre a educação enquanto uma organização mais ou menos institucionalizada da cultura, na qual se reúnem determinados atores do processo pedagógico. Tais atores passam por um processo de formação determinado, cujos resultados influenciam a própria cultura. Há uma clara intenção propositiva no texto: é preciso refletir criticamente sobre o formato dos estabelecimentos de ensino do presente, para que se lhes desenhe um formato para o futuro. A crítica ao formato presente é guiada pela visão daquilo que Nietzsche pensa ser o objetivo de toda educação: permitir o aparecimento do gênio e, desta forma, promover o desenvolvimento de uma cultura mais elevada. O principal alvo da crítica é o próprio tempo presente:

e o que nós ousamos esperar do futuro nesse perspectiva, é uma renovação, refresco e purificação do espírito alemão tão geral que, em certa medida, esses estabelecimentos também renasçam a partir dele e então, depois desse renascimento, pareçam ao mesmo tempo velhos e novos: ao passo que, agora, eles procuram em sua grande maioria ser meramente "modernos" e "adequados ao tempo". (BA/EE Introdução, KSA 1, p. 645)

O escrito deriva de uma série de conferências ministradas por Nietzsche no início de 1872. Vale lembrar que as conferências de $\mathrm{BA} / \mathrm{EE}$ foram ministradas quase que em simultâneo à finalização dos trabalhos de impressão de $O$ nascimento da tragédia. Enquanto este último chegava às mãos do público no início de janeiro de 1872, as conferências de BA/EE eram ministradas precisamente nos dias 16 de janeiro, 6 e 27 de fevereiro, 5 e 23 de março (cf. KSA 15, p. 36s.). Inicialmente foram planejadas seis ou sete conferências. Posteriormente, 
o número foi redefinido definitivamente para seis ${ }^{5}$. Por fim, apenas cinco foram realmente ministradas, já que o filósofo enfrentava problemas de saúde naquele momento. Nietzsche tinha a intenção clara de reunir e publicar o material das conferências. De fato, ainda antes de redigir todo o material, o pensador entrou em contato com seu editor, Ernst Fritzsch, para planejar uma futura publicação:

Muito estimado senhor, neste inverno ministrei aqui na Basileia, a pedido da "Sociedade Acadêmica", 6 conferências públicas sobre o tema: "sobre o futuro de nossos estabelecimentos de ensino". Tive aproximadamente 300 ouvintes em cada uma delas: de diversas partes recebi pedidos para mandar publicar essas falas. Porém, importa-me muito que elas sejam bem e belamente impressas. "Se eu lhe comunico tudo isso, então o senhor deve adivinhar o propósito de minha carta. Ora, eu sei que o tema dessas minhas conferências distancia-se ainda mais da esfera de sua editora do que "o Nascimento da Tragédia". Em todo caso, eu gostaria de lhe fazer essa indicação antes de a qualquer outro: e eu ficaria muito contente, se o senhor pudesse acolhê-la. (BVN/CN 1872 204, a Ernst Fritzsch)

Curiosamente a carta dá a entender que todas as conferências já estavam prontas e haviam sido ministradas. Na verdade, ela adianta fatos que não haviam ainda se concretizado, já que foi escrita a 22 de março, ou seja, na véspera da apresentação da quinta conferência ao público. E, como já mencionado, a sexta conferência não chegou a ser proferida; ela sequer chegou a receber uma redação mais acabada. A razão dessa pequena imprecisão na carta talvez seja o fato de que Nietzsche desejava ter em mãos os primeiros exemplares impressos do futuro livro já em 22 de maio do mesmo ano, como ele esclarece na sequência da carta. Sua intenção era divulgar a obra em Bayreuth e na assembleia geral de filólogos e professores alemães de Leipzig.

Ao fim, ele não chegou concluir o projeto. Ao longo de 1872, engavetou definitivamente o texto das cinco conferências ministradas,

${ }^{5}$ Cf. KSA $71870 \underline{8[86]}, \underline{8[87]}$ e $\underline{8[91]}$ falam em 7 conferências, enquanto KSA 71871

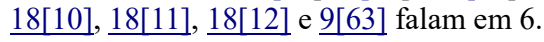


junto a dois esboços de prefácio. A parte final do texto, que se daria na sexta conferência, jamais ganhou uma forma mais acabada e permanece apenas como um conjunto de anotações nos cadernos de Nietzsche. $\mathrm{O}$ mais próximo de uma publicação, que o material de Sobre o futuro de nossos estabelecimentos de ensino conheceu, teve lugar ainda no final de 1872. Naquele momento, um dos prefácios engavetados foi reelaborado e inserido no livro-presente Cinco prefácios a cinco livros não escritos, enviado a Cosima Wagner.

Em termos de estilo, as conferências nos permitem perceber o experimentalismo de Nietzsche. As demais obras do período, sobretudo as publicadas, possuem um caráter expositivo e discursivo mais evidente, com seções mais ou menos longas e normalmente sem título (cf. GT/NT, DS/Co. Ext. I, HL/Co. Ext. II, SE/Co. Ext. III, WB/Co. Ext. IV). Seguindo outra direção, as conferências de BA/EE apresentam-se na forma de um pseudorrelato biográfico. Nietzsche montou nelas um enredo no qual ele mesmo figura como um personagem, narrando um diálogo mais ou menos à maneira de Platão. As conferências descrevem um encontro fortuito que teria ocorrido na juventude de Nietzsche e no qual teriam tomado parte também outros três personagens sem nome: um experiente filósofo, um antigo discípulo desse filósofo e um colega de Nietzsche. O filósofo aguarda pelo encontro com um velho companheiro que, ao que tudo indica, assumiria algum papel importante no diálogo durante a sexta conferência, mas que não surge significativamente no texto até o fim da quinta. No diálogo emergem sucessivamente diversos temas ligados à formação, à cultura e aos estabelecimentos de ensino alemães. $O$ encerramento da quinta conferência é, por assim dizer, bastante pessimista, ao passo que os prefácios sustentam um clima de esperança no futuro, como é comum nos escritos desse período. Aparentemente, isso indica que, talvez, a sexta conferência procuraria retomar um tom esperançoso e confiante em um porvir mais elevado para a cultura alemã. 
O contexto de Schopenhauer como educador é um tanto diferente. Trata-se de um livro efetivamente publicado por Nietzsche e que se enquadra no grande projeto das Considerações extemporâneas. Quatro obras publicadas resultaram desse projeto. Porém, é interessante observar que o objetivo do filósofo alemão era publicar ao menos treze Extemporâneas sobre os mais diversos temas. ${ }^{6}$ Quanto à intenção de publicar um texto sobre Schopenhauer, nota-se que o autor a nutriu por um longo tempo. Não é por acaso que é possível encontrar o texto "A relação da filosofia schopenhaueriana com uma cultura alemã” entre os prefácios de $\mathrm{CV} / \mathrm{CP}$ presenteados a Cosima Wagner em $1872 .{ }^{7}$ No entanto, diferente do que ocorreu com BA/EE, surgiu mais tarde de fato um escrito sobre Schopenhauer. Outra diferença que pode ser notada é que, enquanto $\mathrm{BA} / \mathrm{EE}$ era um escrito praticamente acabado à época de $\mathrm{CV} / \mathrm{CP}$, a Extemporânea sobre Schopenhauer não era mais do que uma intenção, uma ideia a se consumar. Seu traçado - pouco claro naquele momento - ganhou corpo rapidamente em especial em 1874, recebendo sua publicação antes do final daquele ano.

A obra segue o estilo das demais Extemporâneas: um escrito relativamente rápido e provocativo, dividido em cerca de uma dezena de seções sem título e relativamente longas, se comparadas aos estilo aforismático que Nietzsche adotou nos anos seguintes. No caso de Schopenhauer como educador, o texto foi dividido em 8 partes e não conta com prefácios ou introduções. Embora possua traços de relatos

\footnotetext{
${ }^{6}$ Com a passar do tempo e na medida em que as primeiras Extemporâneas foram tomando corpo, Nietzsche modificou constantemente os planos temáticos das obras por vir. Em 2 de setembro de 1873, por exemplo, o tema da Terceira extemporânea seria "muito ler e escrever" (KSA 71872 19[330], cf. também 1873 29[163]). Algum tempo depois o tema passa a ser "filósofo" (KSA 71873 30[38]), depois novamente "ler e escrever" (KSA 7 1874 32[4]). Mesmo em 1876 quando foi publicada a última Extemporânea, novos planos continuaram surgindo (e.g. KSA $81876 \underline{16[10])}$ ).

${ }^{7}$ Antes de se decidir por "Schopenhauer als Erzieher" ("Schopenhauer como educador"), Nietzsche planejou durante algum tempo que o título de sua obra fosse "Schopenhauer unter den Deutschen" ("Schopenhauer entre os alemães"), o que evidencia ainda mais o parentesco da obra de 1874 com a ideia de 1872 (cf. BVN/CN 1874 361, a Carl von Gersdorff).
} 
biográficos, o autor desta vez investe menos energia em anunciar elementos - reais ou fictícios - de sua própria vida (comparativamente a BA/EE). A problemática da educação volta-se mais fortemente aqui para os processos de formação e autoformação do indivíduo. Há, assim, menos destaque às configurações dos estabelecimentos de ensino de seu tempo, embora esse debate ainda esteja presente. Como em BA/EE o texto constrói sua narrativa em vista de uma figura de filósofo, porém agora em SE/Co. Ext. III essa figura recebe um contorno mais específico e um nome: Arthur Schopenhauer.

A despeito de todas as diferenças específicas dos textos, em ambos os casos, o outro é uma figura fundamental para o pensamento pedagógico de Nietzsche. Cabe compreender o que isso pode significar e como esse outro pode atuar em relação ao indivíduo, de modo a responder aos clamores do indivíduo por uma vida autêntica, na qual ele é (ou se torna) quem ele é.

\section{O outro fora do indivíduo e no indivíduo}

Em Nietzsche, o apelo à existência autêntica e autônoma é tão forte que pode muitas vezes turvar nossa percepção quanto à presença do outro em sua reflexão educacional. No entanto, é preciso que se perceba a importância dessa presença. Ela influencia não somente o conteúdo dos textos, mas também a própria forma de exposição dele. Por exemplo, em suas produções iniciais, Nietzsche eventualmente evita anunciar seus pensamentos direta e inequivocamente, por vezes há um outro personagem responsável por sustentar a força argumentativa do texto.

$\mathrm{O}$ caso de BA/EE é bastante exemplar. O personagem Nietzsche possui na obra um papel argumentativo bastante secundário. Dele brotam as memórias, grande parte da descrição do fundo emocional que acompanha o desenrolar do relato, além do próprio ponto de vista do relato em si. Porém, não é de sua boca que partem os principais 
argumentos e teses a se sustentar. O início da trama é permeado por uma trajetória bucólica: o personagem Nietzsche marca um encontro comemorativo com antigos companheiros de estudos em uma paisagem agradável e cercada de boas memórias. O encontro celebraria o sucesso na formação dos personagens envolvidos. Antes da realização da comemoração propriamente dita, o personagem Nietzsche e um colega treinam tiro ao alvo com pistolas quando são interrompidos pelo personagem do filósofo e um discípulo deste. ${ }^{8}$ Essa interferência assinala a ruptura do pano de fundo de contentamento e satisfação que cerca o enredo até então. Nietzsche e seu amigo são duramente repreendidos pelo filósofo, cuja percepção é a de que acontecia ali um duelo.

"Não! Não!, ele nos gritou, aqui não se duelará! Vocês, jovens estudantes, não têm o menor direito a isso! Deixem as pistolas! Acalmem-se, façam as pazes, apertem as mãos! Que? Esse seria o sal da terra, a inteligência do futuro, a semente de nossas esperanças - e não pode se libertar nem sequer do louco catequismo da honra e dos estatutos do direito da força? [...] Vocês querem começar a fazer do código de honra cavalheiresca, isto é, do código da desrazão e da brutalidade a linha-mestra de seu devir? (BA/EE 1, KSA 1, p. 657)

Os jovens reagem de forma altiva e belicosa. Desrespeitosamente explicam que não se tratava de um duelo. Então, quando o personagem do filósofo estava prestes a sair de cena parcialmente contrariado, os jovens disparam mais um tiro. O filósofo queima de ódio: "O que nós devemos fazer? Esses jovens me arruínam com suas explosões!" (BA/EE 1, KSA 1, p. 658). Em seguida, o companheiro do filósofo fala

\footnotetext{
${ }^{8}$ Ao que tudo indica, o personagem filósofo de Sobre o futuro de nossos estabelecimentos de ensino é ao menos parcialmente inspirado em Arthur Schopenhauer. Várias palavras do filósofo parecem espelhar algumas das posições de Schopenhauer, por exemplo contra o duelo (cf. P/P Aforismos para a sabedoria de vida IV), contra o barulho (cf. P/P Sobre o barulho e o ruído) e também contra a filosofia nas universidades (cf. P/P Sobre a filosofia universitária).
} 
aos jovens: "Pois, os senhores têm de saber, [...] que seus passatempos explosivos são, no presente caso, um verdadeiro atentado contra a filosofia" (BA/EE 1, KSA 1, p. 658).

Com a conversa que se segue, a tensão entre eles diminui gradativamente e ambos os grupos descobrem que haviam combinado encontros na mesma localidade. Para acabar com o resto da animosidade que ainda persistia, aceitam dividir o espaço de encontro. Posteriormente, já durante as reuniões dos dois grupos que se concentram a pouca distância um do outro, o personagem Nietzsche passa a dar mais e mais atenção à conversa do grupo do filósofo, deixando em segundo plano seu próprio grupo. Após algum tempo, ele busca definitivamente a companhia do filósofo, para lhe direcionar algumas perguntas e manifestar sua admiração por tudo aquilo que até então ouvira indiscretamente.

Torna-se a partir daí cada vez mais evidente que o personagem filósofo, não Nietzsche, é o porta-voz das principais teses do texto. $\mathrm{O}$ diálogo com os demais personagens não se caracteriza por colocá-lo em dúvida quanto às próprias opiniões ou o induzem a negá-las. Muito pelo contrário, serve-lhe como ocasião para expor e desdobrar seus pensamentos. O personagem Nietzsche, por sua vez, passa por uma mudança de postura significativa ao longo das conferências: de um primeiro momento de soberba e satisfação consigo mesmo, ele começa a manifestar admiração e mesmo certa devoção ao filósofo. $O$ personagem Nietzsche é colocado em posição de perplexidade quanto a seu próprio presente e passado, em dúvida a respeito do sucesso e valor de sua própria formação. Em outras palavras, na dinâmica narrativa de Sobre o futuro de nossos estabelecimentos de ensino, o outro, representado pelo personagem filósofo, é fundamental para a reflexão sobre si mesmo.

O caso de Schopenhauer como educador também é digno de nota. O livro inteiro é perpassado pela preocupação com a autoformação e com o cultivo do indivíduo e a elevação da cultura. A identidade 
pessoal de um indivíduo é, portanto, fundamental na sustentação das teses do texto. Nesse sentido se apresentam passagens como as seguintes: "O homem que não quer pertencer à massa precisa apenas parar de ser acomodado contra si mesmo; ele deve seguir sua consciência que lhe clama: 'seja você mesmo! Você não é nada disto que você agora faz, opina, anseia"” (SE/Co. Ext. III 1, KSA 1, p. 338); e "Diante de nós mesmos, temos a assumir a responsabilidade por nossa existência" (SE/Co Ext. III 1, KSA 1, p. 339). No entanto, apesar da preocupação com sua própria formação e com sua própria identidade pessoal, Nietzsche não clama por uma vida ou uma educação completamente destituída do outro. Pelo contrário, busca precisamente a presença do outro, mais especificamente de um guia, de um filósofo educador.

Quando eu outrora divagava ao sabor de meus desejos, imaginava que o destino tiraria de mim o terrível esforço e obrigação de educar a mim mesmo: visto que eu encontraria no momento certo um filósofo como educador, um verdadeiro filósofo, a quem se pudesse obedecer sem maiores ressalvas, porque se confiaria nele mais do que em si próprio. (SE/Co. Ext. III 2, KSA 1, p. 341s.)

Não é de se ignorar, que a presença de um tal educador não representa simplesmente a existência de uma inspiração distante, mas antes uma imagem sobre a qual Nietzsche espera poder confiar mais do que em si mesmo. O outro, exterior ao indivíduo, desempenha na Terceira extemporânea o mesmo papel do outro de Sobre o futuro de nossos estabelecimentos de ensino: ele é o garantidor de uma formação adequada e autêntica, enquanto há alguma medida de submissão a ele. Sem dúvida, essa ideia é coroada pela passagem seguinte:

Eu pertenço aos leitores de Schopenhauer que depois de terem lido sua primeira página, sabem com certeza que lerão todas as demais e acatarão cada palavra que, de todo, ele tenha dito. Minha confiança nele foi imediata e é ainda agora a mesma de nove anos atrás. Eu o compreendia como se ele tivesse escrito para mim: para me expressar 
compreensível, porém imodesta e insensatamente. É em razão disso que eu nunca encontrei nele um paradoxo, somente um pequeno erro aqui e ali; pois o que são paradoxos, senão afirmações que não inspiram nenhuma confiança, porque o autor mesmo as fez sem legítima confiança, porque, com elas, ele queria fascinar, seduzir e, de maneira geral, aparecer? Schopenhauer nunca quer aparecer: pois ele escreve para si e ninguém quer, de bom grado, ser enganado, menos ainda um filósofo que até mesmo erige para si como lei: não engane ninguém, nem sequer você mesmo. Nem mesmo com o prazeroso engano social, que quase toda conversa traz consigo e o qual o escritor imita quase inconscientemente; ainda menos com o engano consciente de cima do púlpito e com os meios artificiais da retórica. Ao invés disso, Schopenhauer fala consigo: ou, caso se deseje de toda forma imaginar um ouvinte, que se imagine o filho que é ensinado pelo pai. Trata-se de uma exposição sincera, dura e de bom coração, diante de um ouvinte que ouve com amor. Faltam-nos tais escritores. (SE/Co. Ext. III 2, KSA 1, p. 346s.)

Embora se tratem de textos cuja principal preocupação é a educação, tanto no caso de BA/EE quanto no caso de SE/Co. Ext. III, vale a pena observar que a figura que inspira Nietzsche não é exatamente a figura de um professor ou de uma instituição específica. $\mathrm{O}$ filósofo de $\mathrm{BA} / \mathrm{EE}$ é alguém que, tendo lecionado no passado, há muito se afastou das salas de aula e do contato direto com alunos. Dessa posição de distanciamento profere seus discursos a indivíduos que estão mais estritamente relacionados aos estabelecimentos de ensino. Por sua vez, a figura de Schopenhauer em SE/Co. Ext. III é ainda mais paradoxal. Como se sabe a partir das biografias do filósofo Schopenhauer, ele nunca obteve sucesso como professor, tendo desistido rapidamente da carreira acadêmica (e.g. WEISSMANN, 1980, p. 93ss.). Mesmo no que concerne ao contato com leitores de sua obra, é digno de nota que apenas tardiamente ele pode contar com um pequeno grupo de admiradores, com quem se correspondia e cuja visita ele recebia eventualmente. Somente em seus últimos anos de vida, após a publicação de Parerga e Paralipomena (1851), Schopenhauer se 
tornou um fenômeno europeu e um filósofo largamente conhecido e estudado.

Isso significa que trazer à consciência a figura de um Schopenhauer como educador não é certamente o mesmo de trazer à consciência a figura de um Schopenhauer como professor ou doutrinador em sentido estrito. Quero dizer, Nietzsche não encontra em Schopenhauer um plano de vida minuciosamente traçado e definido, que representaria um desencargo completo para o indivíduo que o adotasse. Tampouco os ensinamentos schopenhauerianos são tomados pura e simplesmente como dogmas a serem seguidos. Embora escreva um texto com tons panegíricos, Nietzsche não prega a submissão absolutamente cega a um vulto histórico qualquer. Portanto, a admiração e devoção que surgem em BA/EE e SE/Co. Ext. III, voltadas respectivamente à figura do filósofo sem nome e à figura do filósofo Schopenhauer, não devem ser entendidas como um esquecimento completo de si mesmo, de sua própria identidade e individualidade.

Deve-se lembrar novamente que os dois textos são justamente obras que incitam ao respeito pela própria individualidade pelo Selbst próprio do leitor: "No fundo, cada ser humano sabe, por certo, que está no mundo como algo único somente uma vez e que mais nenhum acaso tão singular agitará, pela segunda vez, uma pluralidade tão estranhamente variada até a uniformidade que ele é" (SE/Co. Ext. III 1, KSA 1, p. 337). Sendo assim, a passagem da autossatisfação - do contentamento com sua própria condição atual - à perplexidade não é a completa negação de si mesmo ou um descuido de si; tampouco é a negação da ética da individualidade ou da autenticidade. Trata-se antes do uso de um outro extraordinário para encontrar a si mesmo.

Resta entender, então, como essa tensão entre o indivíduo e o outro fora dele pode ser coerente com a insistência em uma educação para o fortalecimento de si mesmo. Sobre esse ponto já deve estar claro, que a interpretação aqui defendida é a de que o outro fora do indivíduo pode servir como um elemento de desenvolvimento de sua própria 
identidade pessoal. Para fazer isso, ele desempenha o papel de modelo e guia do indivíduo, um guia que não estimula o indivíduo ao simples espelhamento dos vícios e virtudes do próprio guia, senão incita a uma práxis de autodisciplina e fortalecimento de si.

A importância do guia reside no fato de que, para Nietzsche, exigir de um jovem que manifeste prematuramente a todo custo e a todo momento pensamentos próprios, personalidade e individualidade é um erro. Exigir que desenvolva a si mesmo sem modelos ou guias representa um grande risco de frustrar o próprio desenvolvimento desse jovem. Trata-se de uma prática verdadeiramente antipedagógica (BA/EE 2).

A tese de que um outro fora do indivíduo pode ser útil à formação do indivíduo não é, contudo, uma solução suficiente para todos os problemas levantados por Nietzsche. É preciso ainda complementá-la com a importante e paradoxal ideia de que o indivíduo pode, de alguma maneira, portar nele mesmo algo que não corresponde ao seu si-mesmo (Selbst). O outro não é apenas algo ou alguém que influencia de fora, mas também algo que coabita o indivíduo.

Pois bem, por que elencar no indivíduo tais elementos estranhos à identidade do indivíduo é importante para interpretar as perspectivas educacionais de Nietzsche? A meu ver, principalmente porque a aparente sujeição às figuras dos filósofos em BA/EE e SE/Co. Ext. III, ou seja, a submissão ao outro fora de si, passa a significar duas coisas: (1) a desconfiança, a não aceitação e o combate de outras coisas fora do indivíduo; e (2) a desconfiança, a não aceitação e o combate de algo no indivíduo. A primeira diz respeito, de fato, principalmente ao outro-exterior; a segunda mais propriamente ao outro-interior. Vejamos então a seguir o funcionamento desse duplo aspecto do outro na pedagogia nietzschiana.

O que há a ser combatido fora do indivíduo está razoavelmente claro pelo projeto filosófico das Extemporâneas: o próprio tempo e 
aquilo que é agora conforme o tempo. ${ }^{9}$ Para Nietzsche, a educação alemã que lhe é contemporânea configura-se como uma conformação do indivíduo aos moldes da época, o que significa que a educação está sujeita $\mathrm{e}$, ao mesmo tempo, sujeita o indivíduo às tendências deficientes que dominam aquela época. Dentre essas tendências podem ser destacadas: a erudição excessiva, a cultura jornalesca, a submissão dos grandes pensadores ao Estado, a massificação dos indivíduos, a liberalidade universitária e ginasial, o desligamento das ciências em relação à vida, a cultura excessivamente comercial, ausência de uma verdadeira unidade de estilo. Essas diversas tendências se encontram na formação e no intelectual alemão, de modo que aqueles que Nietzsche chama de "filisteus da cultura" ganham de toda parte atenção e ouvidos. ${ }^{10} \mathrm{O}$ problema de uma educação nesses moldes é que ela se torna infrutífera e, portanto, incapaz de realizar sua missão: dar condições para o surgimento do gênio e, através dele, para a elevação

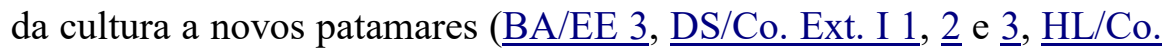
$\underline{\text { Ext. II } 4}$ e $\underline{6}, \underline{\text { SE/Co. Ext. III } 3}$ e $\underline{6})$.

Em última instância, o filósofo de BA/EE e Schopenhauer em SE/Co. Ext. III - entre as demais figuras dignas de elogio nas Extemporâneas como um todo - não representam simplesmente um outro entre os outros, senão o inverso, eles são figuras que simbolizam a extemporaneidade desejada por Nietzsche: eles são o outro contra os outros, contra aqueles que lutam em prol das condições de barbárie cultivada atuais. Eles são grandes homens contra seu tempo, que são capazes de suportar e superar todas as cicatrizes que devem carregar como resultado de sua luta extemporânea. Suas ações não resultam

\footnotetext{
${ }^{9} \mathrm{O}$ título original das Considerações extemporâneas é Unzeitgemäße Betrachtungen. $\mathrm{O}$ termo-chave aqui é o adjetivo unzeitgemäß, que é composto pelo prefixo de negação "un-" somado ao substantivo Zeit ("tempo") e ao termo gemäß, o qual guardo o sentido de "conforme", "adequado", "de acordo com a medida". Ou seja, Unzeitgemäße Betrachtungen são considerações que não estão adequadas ao tempo presente, não estão conformadas pelo tempo presente ou não estão de acordo com a medida do tempo presente.

${ }^{10}$ Esse seria o caso, por exemplo, daquele que foi usado como tema da Primeira extemporânea, David Strauss.
} 
apenas em algo benéfico para si mesmos, mas são também benéficas e criadoras para a cultura, na educação, na literatura, na filosofia, na música ou mesmo nas ciências.

Pensando agora mais diretamente na dinâmica interna dos dois textos-base deste artigo, observe-se que o filósofo de BA/EE é alguém que, em diálogo com os demais personagens da narrativa, denuncia a condição atual e submissa ao tempo das instituições educacionais alemãs. O personagem é também um indivíduo experiente e que, de certa forma, carrega consigo a autoridade para falar da época, uma autoridade tal que o personagem Nietzsche não tem. A figura de Schopenhauer em SE/Co. Ext. III, por sua vez, desempenha um papel muito semelhante. $\mathrm{Na}$ obra, Nietzsche ambienta seu encontro com Schopenhauer descrevendo um cenário de angústia e certo desespero, ${ }^{11}$ no qual ele mesmo anseia por uma formação mais elevada, assim como já está consciente de certos elementos menos elevados da cultura da época. Porém, naquele momento ele não se sente como alguém que pode alcançar seu objetivo por si mesmo, tendo necessidade do apoio de uma figura externa.

Em suma, o modelo, isto é, o outro-exterior representa, portanto, alguém que luta contra forças bárbaras e barbarizantes fora do narrador. Também podemos dizer que o outro fora do indivíduo, enquanto representante de forças e personalidades únicas, denuncia alguma coisa que também se encontra fora do indivíduo, uma coisa tal que corresponde à debilidade e mediocridade que ameaçam o indivíduo desde fora. Ao fazer essa denúncia, esse outro-exterior fornece ao indivíduo também algumas ferramentas para combater a exterioridade débil. $^{12}$

\footnotetext{
${ }^{11}$ Essa é uma diferença curiosa entre os dois textos. Enquanto BA/EE começa sob uma atmosfera de satisfação e comemoração, SE/Co. Ext. III indica justamente um cenário oposto. Nietzsche pinta para este último texto um quadro inicial de angústia e incompletude. ${ }^{12}$ As ferramentas podem ser variadas e dependem tanto do modelo quanto de quem se inspira no modelo. Isso é evidenciado, por exemplo, pelos diferentes papéis que Nietzsche atribui aos diferentes tipos de história na Extemporânea intitulada "Da utilidade $e$
} 
Vejamos agora o segundo aspecto do outro-exterior nos textos pedagógicos do jovem Nietzsche. O outro, como um modelo que educa, não é apenas um exemplo de homem combatente e vitorioso contra seu contexto histórico e cultural específico. Ele possui ainda um papel admoestador e provocativo: indica a necessidade de observação e combate ao outro degenerador dentro do indivíduo. A existência de um outro-interior pode não ser muito clara a um primeiro olhar, mas atentemos à citação abaixo, pois ela joga alguma luz sobre esse problema:

Agora, se se preferir ver todo grande homem também como o genuíno filho de seu tempo e, em todo caso, sofre em todas as suas deficiências mais forte e sensivelmente do que todos os pequenos homens, então a luta de um tal grande contra seu tempo é aparentemente apenas uma luta sem sentido e destrutiva contra si mesmo. Mas precisamente apenas aparentemente; pois, no tempo, ele combate aquilo que o impede de ser grande, o que significa para ele apenas: ser livre e totalmente ele mesmo. Disso segue-se que sua hostilidade é no fundo dirigida precisamente a isso que até mesmo se encontra nele mesmo, mas que não é propriamente ele mesmo, mais especificamente contra a confusão e justaposição de elementos que não se misturam e são eternamente incompatíveis, contra a falsa aglutinação do que é conforme ao tempo [Zeitgemässen] em sua extemporaneidade [Unzeitgemässes]; e

desvantagem da história para a vida". Caso se entenda o uso das figuras de Schopenhauer e Wagner nas Terceira e Quarta extemporâneas como usos da história monumental, se é forçado a admitir que não se deve esperar que essas figuras sejam modelares para todo e qualquer indivíduo. Para cada tipo de pessoa, um diferente tipo de história é uma ferramenta mais adequada: "Cada um dos três tipos de história existentes encontra-se com justeza apenas precisamente sobre Um solo e sob Um clima: sobre outro solo qualquer, ela cresce se transformando em uma erva daninha devastadora. Em geral, se o homem que quer criar coisas grandes precisa do passado, ele se apodera dele por meio da história monumental; quem deseja, ao contrário, manter-se no habitual e longamente venerado, cultiva o que passou como um historiador antiquário; e agora aquele a quem a carência presente oprime o peito e quer retirar de sobre si o fardo a qualquer preço, tem a necessidade da história crítica, isto é, da história que julga e condena. Da transposição irrefletido das plantas a outros terrenos provêm diversos males: o crítico sem necessidade, o antiquário sem piedade, o conhecedor do grande sem a capacidade do grande são tais plantas crescidas como ervas daninhas, alienadas de seu solo materno natural e, por isso, degeneradas" (HL/Co. Ext. II 2, KSA 1, p. 264s.). 
finalmente o suposto filho do tempo revela-se como apenas seu filho bastardo [Stiefkind]. (SE/Co. Ext. III 3, KSA 1, p. 362).

Ora, Nietzsche nos fala da existência de um "isso que até mesmo se encontra nele mesmo, mas que não é propriamente ele mesmo". ${ }^{13}$ Em outras palavras, o outro-exterior fortalecedor, além da função de denunciar e lutar contra o outro-exterior enfraquecedor, possui então desde o princípio o papel de denunciar os modos de ser demasiadamente conformados com o tempo (o outro-interior debilitante) que se expressam dentro de si e da figura do próprio personagem Nietzsche.

Em um primeiro momento de $\mathrm{BA} / \mathrm{EE}$, o personagem do filósofo não é bem recebido pelo personagem Nietzsche. Ele representava apenas um estorvo e uma pessoa que havia interpretado mal suas verdadeiras intenções. No decorrer das conferências, sua função muda completamente. A raiva e o desprezo iniciais, que o personagem Nietzsche manifestara, convertem-se em uma admiração profunda. Em parte, isso acontece porque o filósofo é aquele que evidencia o quão despreparado estava o personagem Nietzsche na busca de uma verdadeira formação.

Antes mesmo do contato com os filósofos-modelo, o caminho percorrido pelo personagem Nietzsche e também os anseios que ele declara sentir são indicativos que algo nele não se contentava plenamente com uma formação vulgar e anseios vulgares, típicos da educação que lhe é contemporânea. Isso é mais óbvio em

\footnotetext{
${ }^{13}$ Percebemos aqui a presença de uma ideia que se tornou cada vez mais importante na produção posterior de Nietzsche. Quero dizer, a ideia de que o indivíduo não é de fato um individuum, ou seja, um entidade indivisível (cf. NF/FP 1875 3[75] e NF/FP 1881 11[56]). No limite, isso nos conduz à ideia de que o indivíduo é um composto de diversas forças em luta; uma ideia bastante explorada pela Pesquisa Nietzsche, principalmente quando focada nas obras posteriores à Assim falou Zaratustra (e.g. MARTON, 2000; MÜLLER-LAUTER, 1997 e 2009). Nem tudo o que pode ser encontrado em um indivíduo é pertencente àquilo que podemos chamar de seu Selbst, sua natureza íntima, seu si-mesmo. O que faz um grande homem não é apenas sua luta contra elementos que lhe são externos, mas também sua luta contra elementos interiores.
} 
Schopenhauer como educador, mas também pode ser percebido em Sobre o futuro de nossos estabelecimentos de ensino. Por exemplo, a narrativa mostra um relativo grau de desligamento do personagem Nietzsche em relação à formação típica do tempo moderno, ou seja, de uma formação em vistas da autossubmissão à profissão e ao Estado:

A exploração demasiadamente frequente desses anos [de formação ginasial] pelo Estado, o qual quer obter para si funcionários úteis o quanto antes e quer se assegurar de sua docilidade incondicional por meio de exames demasiadamente fatigantes, permaneceu à mais longa distância de nossa formação; e quão pouco nos determinou qualquer espírito utilitário, qualquer intenção de veloz ascensão e de fazer carreira rapidamente, cada um de nós percebeu que, no estado de coisas que hoje parece consolador, nós não sabíamos o que nós deveríamos nos tornar, sim percebemos que nós não nos preocupávamos nem um pouco com isso. (BA/EE 1, KSA 1, p. 663s.)

Tudo isso corresponde a certas forças do personagem Nietzsche que resistiram contra a vulgarização e barbarização do tempo presente. A existência de tais impulsos mais nobres em sua natureza não significa, contudo, que uma formação e decurso de vida mais fortes e criadores estão plenamente assegurados. Espreita-o sempre o perigo de se tornar um "homem de cultura degenerado". Note-se que essa expressão é do próprio Nietzsche. Uma passagem de BA/EE 5 (KSA 1, p. 746) menciona literalmente um "entarteten Bildungsmenschen". Ou seja, há o perigo de se tornar alguém que se perde no caminho de sua própria grandeza, alguém que de alguma maneira deixa corromper seu tipo $(A r t)$, sua natureza íntima.

Nesse sentido, a luta pela identidade própria não se constrói apenas na relação do indivíduo com a exterioridade, mas também no campo de batalha de sua interioridade. A mesma alma jovem que clama ao indivíduo a partir do interior do próprio indivíduo "seja você mesmo!" é aquela que também o informa: "Você não é nada disto que você agora faz, opina, anseia"” (SE/Co. Ext. III 1, KSA 1, p. 338). Tão 
importante quanto o imperativo "seja você mesmo" - como uma indicação da importância do si-mesmo para o indivíduo - são as consequências que se podem desdobrar dele: dizer para uma pessoa que ela deve ser ela mesma significa dizer também que, de algum modo, é possível a essa pessoa não ser ela mesma, ou mesmo que essa pessoa atualmente não é ela mesma. Ou seja, as ações visíveis de um indivíduo (o que alguém faz) podem não corresponder verdadeiramente à identidade dele. Porém, isso não é tudo: seus pensamentos (suas opiniões) e seus desejos (seus anseios), entendidos normalmente como elementos de sua interioridade, também podem não corresponder à identidade própria do indivíduo, ao seu Selbst.

Portanto, mesmo o interior do indivíduo pode ser visto como um território de uma certa alteridade a ser combatida. Isso não significa, contudo, que o combate ao outro-interior deve extirpá-lo e eliminá-lo completamente. Tal ideia não está absolutamente clara nos textos do período das Extemporâneas, porém já pode ser entrevista em Schopenhauer como educador, por exemplo. Lá, Nietzsche nos apresenta aquelas que ele denomina "as duas tendências atuais da educação": (1) procurar fornecer uma formação ampla e mais equilibrada possível; e (2) encontrar o ponto forte do estudante e

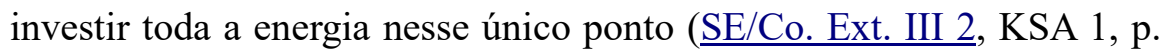
341s.). Para o filósofo alemão, a solução da contradição entre as duas tendências não se resolveria pela adoção irrestrita de apenas uma dela, senão pela percepção de que elas não são absolutamente contraditórias. É possível encontrar um equilíbrio, semelhante a de um sistema solar, entre o fortalecimento do centro de gravidade do indivíduo (seu simesmo) e todo o restante (sua periferia). Sendo assim, o combate ao outro-exterior e ao outro-interior são, antes de tudo, o combate ao desequilíbrio que destitui o indivíduo de seu centro de gravidade, anulando-lhe o Selbst, ou ao desequilíbrio que permite que esse simesmo seja incapaz de criar órbitas ao redor de si. Uma tal incapacidade o tornaria autodestrutivo. 


\section{O si-mesmo no indivíduo e acima do indivíduo}

A educação pode ser entendida como um lugar de encontro do simesmo com o outro. Portanto, está claro que, longe de ser desprezado completamente, o outro tem um papel fundamental no processo de formação do indivíduo criador e, consequentemente, está diretamente relacionado com o modelo de educação e cultura desejados por Nietzsche. Ao mesmo tempo, é igualmente claro que o discurso pedagógico do filósofo alemão não segue em direção a uma entrega e rendição completa a esse outro. Isso implica em dizer que, embora declare que confia completamente em cada palavra de Schopenhauer, nem o personagem Nietzsche, nem o filósofo Nietzsche são verdadeiramente seguidores cegos das verdades de Schopenhauer. ${ }^{14}$ Como já dito, o que faz dele um verdadeiro educador não é seu sucesso ou insucesso como professor universitário, nem mesmo a verdade de sua filosofia teórica, mas, antes e mais importante de tudo, sua capacidade de ser ele mesmo e sua capacidade de dialogar com o clamor da alma jovem pela própria identidade.

A valorização do si-mesmo e do modo como ele se coloca diante de seu tempo é tão importante na produção do jovem Nietzsche que dita a maneira como os textos das Terceira e Quarta extemporâneas abordam as figuras de Arthur Schopenhauer e Richard Wagner. Ao invés de procurar descrevê-los como os grandes filhos de suas

\footnotetext{
${ }^{14}$ Vale observar que Nietzsche sempre se mostrou crítico a diversas posições teóricas de seu mestre, apesar da grande inspiração que buscava nos textos schopenhauerianos, mesmo à época de redação de seus textos juvenis. Um forte indício disso pode ser encontrado, por exemplo, nos fragmentos redigidos entre o outono de 1867 e a primavera de 1868, conhecidos como Zu Schopenhauer ou Sobre Schopenhauer (cf. NIETZSCHE, 2012). Outro indício é uma carta de 1876, escrita portanto à época da Quarta extemporânea e endereçada a Cosima Wagner: "A senhora irá se admirar se eu lhe confessar uma diferença com a doutrina de Schopenhauer, que formou-se gradativamente e como que de súbito surgiu em minha consciência? Eu não estou mais ao lado dele em quase todos os princípios gerais; já quando eu escrevi sobre Sch[openhauer] [na Terceira extemporânea], percebi que passei por cima de tudo de dogmático lá; para mim, situa-se tudo no homem. (BVN/CN 1876 581; cf. também KSA 15, p. 71).
} 
respectivas épocas, o objetivo de Nietzsche consiste em mostrá-los como personalidades em luta contra seu tempo. De modo geral, a preferência por esse modo de encarrar as figuras de admiração já está enunciado desde a Primeira ${ }^{15}$ e a Segunda extemporâneas, como fica evidente pela passagem a seguir:

E se vocês anseiam por biografias, então que não seja por aquelas com o refrão "senhor tal e tal e seu tempo", senão por aquelas que devem ter em em seu frontispício "um combatente contra seu tempo". Satisfaçam suas almas com Plutarco e atrevam-se a acreditar em vocês mesmos, ao acreditar em seus heróis. Com uma centena de tais homens educados de modo não moderno, isto é, maduros e acostumados ao heroico, pode-se agora silenciar toda a barulhenta pseudo-formação de nosso tempo. (HL/Co. Ext. II 6, KSA 1, p. 295)

Tendo tudo isso em vista, resta perguntar: o que pode ser entendido mais precisamente sob a rubrica de Selbst (si-mesmo) nas obras do jovem Nietzsche. Embora seja um conceito central nessas obras, ao procurar a resposta a tal questão nos textos das Extemporâneas e outras publicações do período, não se encontra nenhuma definição lapidar e longamente explicitada.

Tento me aproximar a seguir de um entendimento do conceito de si-mesmo no jovem Nietzsche. Parto das pistas que podem ser encontradas nos textos ora investigados para dar fundamento a uma interpretação da questão. Além disso, persigo também a hipótese de que a teoria de identidade pessoal nietzschiana guarda forte parentesco com a teoria do caráter de Schopenhauer, sendo-lhe simultaneamente tributária e crítica. ${ }^{16}$ Isso significa que as características mais centrais

\footnotetext{
${ }^{15}$ Quanto a Primeira extemporânea, note a energia que Nietzsche emprega justamente no sentido de denunciar Strauss por ser demasiadamente conformado ao seu tempo (e.g. DS/Co. Ext. I 8) e, portanto, indigno da mesma admiração ofertada às figuras das duas últimas Extemporâneas.

${ }^{16} \mathrm{Um}$ indício forte dessa aproximação encontra-se na adoção por Nietzsche de uma expressão empregada em Sobre o fundamento da moral, um dos textos-base no estudo da teoria do caráter em Schopenhauer. Em Da utilidade e desvantagem da história para a vida,
} 
do conceito de si-mesmo podem ser obtidas em contraste com os conceitos schopenhauerianos.

Segundo a teoria schopenhaueriana do caráter, o ser humano individual, homem concreto no tempo e no espaço, é o resultado da manifestação de sua essência íntima. Essa essência íntima pode ser chamada de "vontade individual" ou de "caráter inteligível". Toda ação é, desta forma, uma manifestação da identidade própria do indivíduo, do fundo volitivo que o configura como ele é em essência. Nas palavras de Schopenhauer, o "caráter inteligível coincide pois com a Ideia ou, mais propriamente, com o ato da vontade original que se manifesta nela" (WWV I/MVR I 28, Zürcher 1, p. 208). O termo Ideia representa para Schopenhauer um conceito próximo ao de Platão. Ou seja, Ideia não é um ato de pensamento, mas uma realidade metafísica que, sendo imutável e pertencendo à esfera do ser, dá origem a acontecimentos no mundo físico (esfera da mutabilidade, do vir-a-ser).

Todo acontecer é manifestação da vontade metafísica e, mais especificamente no caso do ser humano, toda ação de uma pessoa é uma manifestação de seu caráter inteligível. Ao entrar em contato com uma situação concreta, cada indivíduo age de acordo com sua identidade íntima. Tais situações podem ser entendidas, portanto, como ocasiões de ação e, por mais que alguém possa ser constrangido exteriormente para agir de um modo ou outro, a definição da ação desse alguém ocorre essencialmente desde o interior. Seu caráter, no entanto, não corresponde à porção consciente do indivíduo, mas pelo contrário,

\footnotetext{
Nietzsche diz: "Strauss não aprendeu sequer que um conceito jamais pode fazer dos homens seres mais morais e melhores, e que tão mais fácil é pregar a moral quanto mais difícil é fundamentar a moral [und dass Moral predigen eben so leicht als Moral begründen schwer ist]" (DS/Co. Ext. I 7, KSA 1, p. 195). Por sua vez, Schopenhauer apresenta como mote de seu texto o seguinte: "Pregar a moral é fácil, fundamentar a moral difícil [Moral predigen ist leicht, Moral begründen schwer]" (M/M, Züricher 6, p. 143). A passagem se encontra quase idêntica também em Sobre a vontade na natureza, um texto que procura fortalecer a tese de que há um fundo íntimo volitivo em todo acontecer: "Daí resulta que pregação moral é fácil, fundamentação moral é difícil $[D a$ ergiebt sich, daß MoralPredigen leicht, Moral-Begründen schwer ist]" (N/N Indicações à ética, Zürcher 5, p. 336).
} 
o caráter inteligível de alguém só é acessível indiretamente, inclusive por ele mesmo. Ninguém conhece a si mesmo em um único ato cognitivo qualquer. Só se pode conhecer a si mesmo a posteriori. Em outras palavras, o conhecimento de si mesmo ocorre apenas através da observação das ocasiões de ação da exterioridade e as respectivas ações, afetos e paixões da interioridade do indivíduo. ${ }^{17}$

Em um plano mais geral, as características até aqui levantadas do conceito schopenhaueriano de caráter são também as características do Selbst nietzschiano, exceto seu caracterização como "imutável" e "metafísico". Também para Nietzsche, não existe um acesso completo e imediato ao si-mesmo, entendido como a fonte profunda de um agir no mundo. Conhecer-se ou conhecer outrem é conhecer pelas ações do indivíduo no mundo, como se cada ação fosse um testemunho parcial de sua natureza íntima. Todavia, dois fatores devem ser levados em consideração. Em primeiro lugar, deve-se ter em mente que o ser humano é extremamente complexo em seu plano volitivo. Daí resulta que não é possível deduzir facilmente um caráter/Selbst a partir de uma ação qualquer e isolada. Em segundo lugar, deve-se perceber que a capacidade intelectual do ser humano torna-o ainda mais complexo. Isso significa que um ser humano dissimula para o outro e para si desejos e ações de modo intencional ou não intencional. Em consequência, poderíamos dizer que as ações são espelhos da identidade íntima do indivíduo, porém são espelhos distorcidos, cujos reflexos, como o de qualquer espelho, não são diretos e, nesse caso, tampouco nítidos.

\footnotetext{
${ }^{17}$ Por esse motivo, Schopenhauer afirma que "o intelecto é originalmente bem estranho às decisões da vontade. Ele entrega a ela os motivos: mas que efeito terão, ele só vem a saber depois, completamente a posteriori; como quem faz um experimento químico e coloca os reagentes em contato, para então esperar o resultado. Sim, o intelecto encontra-se tão excluído das verdadeiras resoluções e decisões secretas da vontade própria, que ele só pode conhecê-las ocasionalmente, assim como as de um estranho, apenas por meio da espreita e da surpresa, e precisa pegá-la em flagrante no ato de suas externações, para descobrir suas verdadeiras intenções” (WWV II/MVR II cap. 19, Zürcher 3, p. 243).
} 
Ao que tudo indica, a distinção mais fundamental das teorias de identidade pessoal de Schopenhauer e Nietzsche é a rejeição na perspectiva nietzschiana à metafísica em sentido forte proposta por Schopenhauer. Para este último, o caráter inteligível, ou seja, o que alguém é essencialmente, encontra-se fora do tempo, do espaço e consequentemente da causalidade. Daí resulta que ele não pode ser adequadamente descrito em termos físicos e que tampouco está sujeito a mudanças. Em Nietzsche, encontramos por sua vez um ponto de vista diferente: tal essência profunda do nós mesmos é uma força entre outras forças no mundo, ou seja, está sujeita a mudanças, transformações e corrupções.

Nesse ponto é preciso fazer um esclarecimento. É bastante consensual a interpretação de que a crítica à metafísica está presente no mínimo desde Humano, demasiado humano. Contudo, nem sempre se reconhece que Nietzsche rejeitava uma metafísica rigorosa ainda na primeira fase de seu pensamento. Aceitar a existência dessa rejeição é importante neste momento, pois ela indica um ponto de ruptura fundamental e primordial entre as teorias schopenhaueriana e nietzschiana. Ainda que as linhas gerais de suas teorias do caráter sejam semelhantes, podemos perceber que Nietzsche tenta encontrar formas alternativas de fundamentar seus pontos de vista. Dito isso, exponho a seguir quatro argumentos para indicar a presença constante de uma visão de mundo não metafísica no jovem Nietzsche. Com isso espero evidenciar que o Selbst não deve ser interpretado como uma essência imutável do indivíduo.

O primeiro argumento é: a despeito de falar de uma "metafísica de artista" (e.g. GT/NT TA 2, TA 5 e TA 7), Nietzsche mostra-se descrente quanto à possibilidade de se criar uma metafísica em sentido rigoroso, mesmo antes de redigir $O$ nascimento da tragédia (1871/1872). Tal "metafísica de artista" seria, na verdade, uma ficção edificante. Ou seja, ela seria uma perspectiva que não é rigorosamente verdadeira, mas, dado que nenhuma perspectiva poderia ser encarada como uma 
"verdade absoluta", seria ao menos uma perspectiva com a qual se pode melhor viver e criar. ${ }^{18}$ Há indícios de que Nietzsche trabalhava com essa ótica no mínimo desde 1867, como o provam suas anotações conhecidas como "Zu Schopenhauer" (NIETZSCHE, 2012). Nesse sentido, as críticas posteriores do próprio autor a $O$ nascimento da tragédia não devem ser entendidas como um abandono de uma metafísica no sentido rigoroso, mas como um reconhecimento de que uma metafísica "do ponto de vista do ideal" ainda é demasiadamente consoladora e não alcança o nível de radicalidade necessário para os propósitos do filósofo.

O segundo argumento é: a posição contrária à metafísica rigorosa não foi abandonada em um momento posterior a $\mathrm{Zu}$ Schopenhauer, pois esse ponto de vista continua presente nos anos posteriores. Isso é evidenciado, por exemplo, pelo texto inacabado Sobre verdade $e$ mentira no sentido extramoral. O texto não apresenta nenhuma metafísica no sentido forte, mas desenvolve a ideia de que determinadas formas de ver o mundo, incluindo as metafísicas e antimetafísicas, decorrem de certas disposições e condições de vida de diferentes tipos de homem. A realidade não é apresentada como uma instância metafísica fixa, senão como um grande fluxo, como um grande vir-a-ser. Enquanto isso, a fixidez e veracidade são apresentadas como criações conceituais que têm o papel de permitir a existência dos homens. Uma metafísica jamais poderia ser entendida efetivamente como uma "ciência da verdade imutável", pois a própria verdade não se distingue essencialmente da mentira.

É certo que o texto de WL/VM jamais foi concluído ou publicado por Nietzsche, porém ideias compatíveis aparecem também em texto publicado. Já no início da Primeira extemporânea, o filósofo alemão faz notar que a busca de uma verdade em si e imutável, fundamental para uma metafísica em sentido rigoroso, não é o centro de gravidade

${ }^{18}$ Sobre o uso da metafísica do "ponto de vista do ideal", veja ITAPARICA, 2004; LOPES, 2008. 
de seu pensamento. Na primeira seção de DS/Co. Ext. I, o autor rotula de "erro" a opinião de que a vitória militar dos alemães na Guerra Franco-Prussiana era uma vitória da cultura alemã sobre a cultura francesa. Antes que o leitor possa pensar que o problema desse pensamento é o fato de ser um erro, o autor assevera que não se deve precipitar. O problema com essa opinião não é o fato de ser um erro, mas suas consequências nocivas; no caso a "extirpação do espírito alemão [des deutschen Geistes] em proveito do 'império alemão' [des „,deutschen Reiches “]” (DS/Co. Ext. I 1, KSA 1, p. 159s.). Essa mesma ideia sobre o erro perpassa todo o texto: David Strauss não é prejudicial porque não consegue formular uma teoria adequada ao em-si do mundo, mas porque tem um efeito enfraquecedor na cultura.

O terceiro argumento: o conceito de Selbst não pode ser entendido como imutável, pois Da utilidade e desvantagem da história para a vida, publicado apenas alguns meses antes de Schopenhauer como educador, explicitamente não corrobora com um conceito de identidade pessoal imutável. A Segunda extemporânea não só reforça a ideia de mutabilidade do caráter, como também fornece uma ferramenta para entendermos os processos de transformação do si-mesmo ao trabalhar com as noções de primeira e de segunda naturezas. ${ }^{19}$

\footnotetext{
${ }^{19}$ Dos três modos de considerar a ciência histórica, a história crítica se relaciona mais explicitamente com o problema da mutabilidade do caráter do que as demais. Fala-se nesse caso de transformar uma natureza herdada; enquanto a história monumental fala de naturezas fortes, sem deixar clara a possibilidade e/ou necessidade de conservação ou transformação da natureza do indivíduo; e a história antiquária fala mais precisamente de conservação dessa natureza. A história crítica se caracteriza justamente pelo confronto contra uma certa natureza que está posta e impõe a necessidade de se fazer algo com ela: "Se condenamos aquelas aberrações e nos tomamos por exonerados delas, o fato que provimos delas não está eliminado. No melhor dos casos, levamos isso a um confronto da natureza herdada e ancestral e nosso conhecimento, certamente também a uma luta de um novo e rigoroso cultivo contra o tradicionalmente absorvido e hereditário, nós plantamos um novo hábito, um novo instinto, uma segunda natureza, tal que a primeira natureza comece a secar. É uma tentativa de se dar como que um passado a posteriori, do qual se gostaria de provir, em contraposição àquele do qual se provém - sempre uma tentativa perigosa, porque é bem difícil encontrar um limite na negação do passado e porque as segundas naturezas são, na maioria das vezes, mais fracas do que as primeiras. Fica-se de
} 
Essas noções propõe que, a natureza mais íntima de um indivíduo (primeira natureza) esta sujeita a influência de outro elemento que o compõe ainda que apenas de maneira secundária (segunda natureza). Uma segunda natureza é mais frágil e maleável do que uma primeira natureza, mas com a influência do tempo, do hábito e de pressões várias, uma segunda natureza pode se tornar em um indivíduo uma primeira natureza. Em outras palavras, o caráter mais profundo de um indivíduo é passível de modificações, portanto não é metafísico. Isso não quer dizer que uma modificação da primeira natureza seja rápida ou fácil. Pelo contrário, ela funcionaria como uma espécie de núcleo mais duro e mais profundo do indivíduo, mais resistente a transformações radicais. A tentativa de provocar a todo custo uma mudança na primeira natureza pode inclusive colocar em risco a própria existência do indivíduo.

Pode-se dizer então que não é um Selbst imutável que está em jogo no texto de Nietzsche, mas de uma Selbst menos maleável, isto é, mutável apenas a custo de muito esforço e muitos perigos. Dada a profundidade e dureza do si-mesmo de um indivíduo, o resultado de uma tentativa de modificá-lo significativamente através de processos educativos pode significar o enfraquecimento e corrupção do indivíduo. Em verdade, ao que indicam textos mais tardios de Nietzsche, uma modificação bem-sucedida no cerne do homem só pode ocorrer com verdadeiro sucesso ao longo de gerações. Consequentemente, não é facultado a alguém modificar radicalmente seu si-mesmo ao longo de sua própria vida. Tampouco o pode fazer com sucesso uma instituição de ensino. ${ }^{20}$ Exceto algumas transformações pontuais de algumas

modo demasiadamente frequente em um reconhecimento do que é bom, sem fazê-lo, porque também se conhece o que é melhor, sem ser capaz de fazê-lo. Porém, aqui e ali chega-se à vitória afinal, e há até mesmo para os lutadores, para aqueles que se servem da história crítica para a vida, um consolo digno de nota: notadamente, saber que também aquela primeira natureza algum dia já foi uma segunda natureza e que toda segunda natureza vitoriosa torna-se uma primeira. -" (HL/Co. Ext. II 3, KSA 1, p. 270).

${ }^{20}$ A ideia de que há algo que não é passível de formação no indivíduo aparece, por exemplo, na seguinte anotação póstuma da época de preparação de BA/EE: "A formação só pode se referir ao que é passível de formação. Não ao caráter inteligível” (NF/FP 1870 8[92]). 
"segundas naturezas" em "primeiras" ao longo da vida, ${ }^{21}$ o mais longe que indivíduos e instituições podem ir é fazer o si-mesmo manifestar-se mais ou manifestar-se menos plenamente conforme ele já é.

Quarto e último argumento: embora Humano, demasiado humano possa ser visto realmente como um momento de ruptura em relação a diversos pontos de vista da produção anterior do filósofo alemão, não há de fato uma ruptura no que concerne à teoria do caráter e à não aceitação da metafísica em sentido rigoroso. Podemos dizer então que a rejeição à metafísica não é de fato o elemento distintivo do período intermediário, cuja obra inaugural seria justamente MAI/HHI. Essa rejeição é uma característica perene na produção nietzschiana. Isso não quer dizer, é claro, que o modo como Nietzsche rejeita a metafísica e as consequências que retira dessa rejeição nos dois períodos sejam precisamente idênticas. A distinção mais evidente entre o período de juventude e o período intermediário seria, destarte, o fato de que Nietzsche já não propõe uma metafísica sequer do ponto de vista do ideal a partir de MAI/HHI. No período inicial, ele parece ainda experimentar a formulação de suas ideias sem uma metafísica subjacente (como o indica a BVN/CN 1876 581). Posteriormente, parece concluir que seu pensamento já está suficientemente maduro para empreender definitivamente a tarefa de pensar para além da metafísica.

No tocante à imutabilidade do caráter, esse movimento se torna claro. Nas obras de juventude, os textos publicados mais sugerem que o caráter não é imutável e que seria possível apresentar uma teoria alternativa, mas não chegam a fazer um enfrentamento definitivo e direto das questões. Nos apontamentos póstumos, o autor faz diversas experiências de pensamento que parecem promover a transição para uma posição mais explícita e declarada. Não obstante, com a entrada no período intermediário, a hipótese da imutabilidade do caráter é posta à

${ }^{21}$ Sobre esse ponto, veja HL/Co. Ext. II 3, FW/GC 356, NF/FP 1885 34[57] e 34[134]. 
prova diretamente nos textos publicados. Não se tratam mais de sugestões, mas de afirmações mais diretas e de um confronto conceitual declarado. Além disso, conceitos como, por exemplo, primeira e segunda natureza, já presentes na juventude com o papel de fornecer uma explicitação não metafísica dos fenômenos do caráter, continuam aparecendo como ferramentas alternativas para a compreensão das transformações do caráter (e.g. M/A 455).

Em suma, ainda que existam diversas modificações nos métodos e consequências, que o filósofo pretende extrair de sua crítica à metafísica, a existência de uma rejeição a doutrinas que postulem uma fixidez absoluta é constante em Nietzsche. No que tange a problemática da identidade pessoal, tal rejeição é interessante porque abre a possibilidade de se pensar em um si-mesmo sujeito a mudanças. No que tange a educação, a mutabilidade do si-mesmo abre o questionamento sobre os limites e possibilidades das transformações no cerne mais fundamental dos indivíduos. Pois é preciso não perder de vista, que a mutabilidade de nossa natureza íntima não pode ser entendida como sinônimo de ausência de toda e qualquer durabilidade de nossa identidade. Ela também não pode ser entendida como uma capacidade ilimitada do indivíduo em mudar a si-mesmo continuamente para qualquer direção.

Em Schopenhauer, é o caráter ( $\tilde{\eta} \theta o \varsigma, \bar{e} t h o s)$ que define o hábito ( $\varepsilon^{\prime} \theta o \varsigma$, ethos), ou seja, nossas ações concretas são fruto de algo que nós somos metafisicamente e, por isso, inalteravelmente. O hábito pode mudar no máximo alguns modos de expressão concretos de nossas ações no mundo, mas não pode jamais mudar a essência mesma dessas ações. Ao passo que, em Nietzsche, encontramos uma via de mão dupla: tanto o si-mesmo ( $\tilde{\eta} \theta o s, \bar{e} t h o s)$ define o hábito ( $\ddot{\varepsilon} \theta o \varsigma$, ethos), quanto o hábito ( $\ddot{\varepsilon} \theta o \varsigma$, ethos) define o si-mesmo ( $\tilde{\eta} \theta o \varsigma$, $\bar{e}$ thos). Nesse sentido, no pensamento de Nietzsche, existe não apenas o perigo de a natureza do indivíduo não conseguir se manifestar completa e diretamente, seja por ocultação, por bloqueio ou 
dissimulação, como na filosofia schopenhaueriana; ela também está sujeita à corrupção, degeneração e deformação. Em outras palavras, pelas pressões do outro fora dele e também do outro nele, o indivíduo pode deixar de ser aquilo que é e se aproximar cada vez mais dos demais, ele se torna então de fato o outro, perde sua identidade própria e se torna como que um produto de fábrica: um outro entre outros desprovido de um si-mesmo que o caracterize de fato, portador de, no máximo, um arremedo de si-mesmo.

Como consequência desse pano de fundo, pode-se considerar então que Nietzsche propõe um tipo de educação que, entendendo-se como uma força externa ao indivíduo, compreende que o trabalho pedagógico não depende unicamente de suas conformações, legislações e metodologias. A transformação mais superficial ou mais radical do indivíduo depende também - e deve depender - da natureza própria do indivíduo em formação. A educação pretendida por Nietzsche é aquela que dá condições para que o si-mesmo se manifeste em consonância com o que ele é em si mesmo, o que significa também que ele se organiza de forma criativa com outras forças ao seu redor (internas e externas). A educação transforma o indivíduo, precisamente porque dá espaço e condições para que o indivíduo transforme a si mesmo:

Ninguém pode lhe construir as pontes sobre a qual você deve agora atravessar sobre o rio da vida, ninguém senão você apenas. É verdade que existem incontáveis trilhas e pontes e semideuses, que querem o carregar através do rio; mas somente ao preço de você mesmo; você penhoraria a si mesmo e se perderia. (SE/Co. Ext. III 1, KSA 1, p. 340)

Nem toda transformação pode contudo ser entendida como positiva, apenas porque é uma transformação. Também não se pode dizer que a transformação constante e radical do Selbst seja um dos objetivos de Nietzsche. O peso da pena do filósofo parece recair para o outro lado, ou seja, para a ideia de que deve-se dar certa constância e força ao si-mesmo. Deve-se permitir que ele siga aproximadamente 
o sentido que já tem, ainda que, para fazê-lo, precise criar toda uma sistema gravitacional com suas alteridades ao redor de sua ipseidade. Uma mudança errática e inconstante do si-mesmo não é sinônimo de força, mas, pelo contrário, é meramente mais uma característica de uma modernidade degenerada. Soma-se assim todo tipo de influência sem a devida organização e sentido, em outras palavras, sem estilo. ${ }^{22}$ Ora, mais é justamente a ausência de um verdadeiro estilo aquilo que caracterizaria, segundo Nietzsche, a formação e cultura alemã contemporânea, das quais David Strauss e os demais filisteus da cultura seria representantes por excelência. Portanto, a educação do indivíduo forte deve ser uma educação do si-mesmo que respeite a dureza do si-mesmo.

Dito isso, gostaria de chamar a atenção para um detalhe notável da teoria nietzschiana do Selbst: ele não pode ser apenas entendido como aquilo que habita o indivíduo e o define enquanto tal, mas deve também ser entendido como algo que está acima do indivíduo.

Vejamos isso com mais vagar. Quando se empregam expressões como "caráter", "natureza íntima", "identidade pessoal”, i.e. quando se fala de um si-mesmo, tende-se a pensar que essas expressões se referem a algo de fixo e muito preciso dentro de um indivíduo. Como tal, o aspecto mais destacado dessa natureza íntima seria uma certa tendência a permanecer sempre semelhante a si, como um todo acabado. Além disso, caso alguém quisesse conhecer a si mesmo - ou conhecer o seu si-mesmo -, sua própria interioridade seria apontada como o caminho dessa descoberta: para conhecer a si mesmo bastaria, de algum modo, olhar para dentro de si mesmo. Porém, o caminho de Nietzsche é outro.

Ainda que a auto-observação possa contribuir para o processo de autoconhecimento, ela não pode ser resumida em um mero olhar-paradentro. Uma auto-observação, por mais profunda que possa ser, não consegue penetrar tão completamente nosso ser próprio. Nas palavras

\footnotetext{
${ }^{22}$ Sobre o estilo, confira BA/EE 2, DS/Co. Ext. I 1, HL/Co. Ext. II 4, WB/Co. Ext. IV 10.
} 
do filósofo alemão: "Ele [o ser humano] é uma coisa obscura e encoberta; e se a lebre tem sete peles, o ser humano pode despir-se sete multiplicado por setenta vezes e, entretanto, não poderá dizer 'ora, isto é você de fato, não é mais casca"” ( $\mathrm{SE} / \mathrm{Co}$. Ext. I 1, KSA 1, p. 340). No limite, o olhar que se lança desesperadamente e cada vez mais fundo para dentro de si mesmo não só é incapaz de revelar o si-mesmo de um indivíduo, mas, além de ineficaz, uma tentativa de aprofundamento em si para o conhecimento de si seria também bastante perigosa e poderia gerar feridas "que nenhum médico pode curar". Assim, é a outro lado que o filósofo dirige o olhar do leitor, ou dito ainda melhor, é para a vida e para as vivências no mundo que se deve voltar a mirada. Para Nietzsche, deve-se olhar justamente os encontros do indivíduo com o mundo, presentes e passados, para melhor conhecê-lo:

E ademais: para que isso [lançar-se profundamente para dentro de si a procura de si] seria necessário, se, porém, tudo dá testemunho de nosso ser, nossas amizades e inimizades, nosso olhar e aperto de mão, nossa memória e aquilo que esquecemos, nossos livros e os traços de nossa pena. Todavia, para realizar o mais importante interrogatório, há o seguinte meio. Que a alma jovem olhe a vida em retrospecto com a pergunta: o que você verdadeiramente amou até agora, o que atraiu sua alma, o que a dominou e, ao mesmo tempo, a fez feliz? Disponha diante de si a série desses objetos venerados, e elas talvez lhe mostrem, através de sua natureza e sequência, uma lei, a lei fundamental de seu próprio si-mesmo. Compare esses objetos, veja como um ao outro completa, alonga, excede, transfigura, como eles formam uma escada com a qual

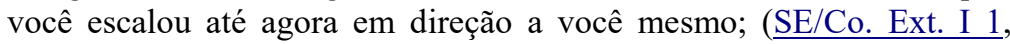
KSA 1, p. 340)

Que alguém não deva se dar por conhecedor de si mesmo cedo demais, é uma consequência interessante retirada por Nietzsche dessas ideias, cuja aplicação em um contexto educativo pode ser frutífero. $\mathrm{O}$ indivíduo que encontra a si mesmo muito cedo está, na verdade, apenas praticando uma forma perigosa de desconhecimento de si. Ele está aceitando como próprias e como seu Selbst uma série de características 
agregadas e parciais. Caso entenda-se como isso ou aquilo cedo demais, ele passa a condicionar sua vida à manutenção dessas características e com isso perde-se e enfraquece-se em louvor de algo que lhe era apenas secundário. Embora tais ou quais características do momento de um tal indivíduo jovem possam ser um caminho para o entendimento do sentido de sua natureza íntima, elas são apenas um indicativo parcial de suas transformações. Portanto, quando ele se acomoda cedo demais a pensar que é isso ou aquilo, ele impede que seu Selbst o conduza além do que ele apresenta agora, que continue sua escalada em direção a si mesmo. Isto posto, em um contexto educacional, a exigência exagerada de que os jovens mostrem personalidade e individualidade rapidamente teria, de acordo com Nietzsche, precisamente o efeito inverso. ${ }^{23}$ Os jovens seriam levados em função disso à corrupção daquilo que lhes é mais próprio.

É preciso, então, considerar mais de perto o final da citação que foi empregada pouco mais acima. Nessa passagem emblemática da Terceira extemporânea, Nietzsche sugere que se compare os objetos que se venerou e se observe "como eles formam uma escada com a qual você escalou até agora em direção a você mesmo". A ideia paradoxal de "escalar em direção a si mesmo" parece fazer eco com a ideia de "tornar-se o que se é", que aparece no subtítulo de Ecce homo. A sequência da passagem é também bastante interessante:

pois seu verdadeiro ser não está escondido nas profundezas de você mesmo, mas imensuravelmente alto acima de você ou, ao menos, acima daquilo que você costumeiramente toma como seu eu. Seus verdadeiros educadores e formadores revelam a você qual é o real sentido originário e matéria-prima de seu ser, algo de absolutamente ineducável e imodelável, mas, de qualquer forma, algo de difícil acesso, algo de amarrado, algo de paralisado: seus educadores não são aptos a ser nada

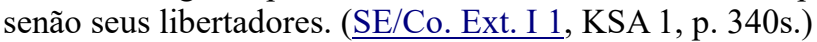

\footnotetext{
${ }^{23}$ De modo geral, essa ideia atravessa o texto de Sobre o futuro de nossos estabelecimentos de ensino e pode ser encontrada com mais facilidade no debate sobre a liberalidade ginasial e acadêmica em BA/EE 5 .
} 
De acordo com o ponto de vista aqui defendido, a ideia de uma identidade própria acima do indivíduo pode ser entendida a partir de uma dupla e paradoxal caracterização do si-mesmo. A primeira já foi discutida longamente neste artigo: não há uma essência absolutamente fixa no ser humano. Mesmo nossa natureza íntima está em transformação, ainda que mais lenta do que os elementos mais superficiais de minha individualidade. É certo que Nietzsche fala de algo "ineducável e imodelável”, entretanto, não podemos nos enganar e daí desdobrar a existência de qualquer essência metafísica do ser humano. Trata-se antes de um fundo mutável, porém inacessível à ação educacional. Sendo o ato educativo uma ação exterior ao indivíduo, ao atingi-lo, ele pode arranhar sua superfície e até penetrar em algumas de suas camadas menos profundas. Porém, por mais intensa que seja uma ação desse gênero, ela não consegue penetrar o si-mesmo radicalmente.

A segunda caracterização é nova: encontramo-nos acima de nós mesmos. Essa colocação está em flagrante contradição com a ideia de profundidade e interioridade do si-mesmo. Para escapar a esse paradoxo, defendo a interpretação de que a sobreposição do si-mesmo ao indivíduo deve ser lida como uma metáfora para a ideia de que o simesmo possui um sentido. A natureza mais íntima do indivíduo não pode ser lida como uma miniatura do indivíduo dentro do indivíduo. A leitura mais adequada seria a de que ela é um conjunto de forças, instintos e impulsos persistentes que lançam o indivíduo e o transformam em um sentido específico. O sentido do si-mesmo está acima do indivíduo concreto e, na medida em que transforma o indivíduo a partir de dentro, eleva-o como um todo além daquilo que ele agora é, naquela direção previamente apontada (acima de si). Esse processo torna o indivíduo aquilo que ele já era, ou seja, o indivíduo realiza em si e como uma totalidade o sentido de seu si-mesmo. Ele transfigurou-se agora como totalidade, como sua natureza íntima somada a todo o agregado que gravita em torno dela, naquilo que ele já prefigurava enquanto sentido do Selbst. Nesse processo do indivíduo 
tornar-se o que seu si-mesmo é, o próprio si-mesmo se transforma e aponta para um novo além.

Não há portanto contradição entre a primeira e a segunda caracterizações do si-mesmo. Elas se completam ao descrever o indivíduo e sua natureza própria como processo e como sentido. Com efeito, o mais importante para compreender a identidade própria de um indivíduo não é afinal como ele se apresenta precisamente agora, mas o sentido de suas transformações, aonde seu si-mesmo o quer levar. $\mathrm{O}$ importante é que o indivíduo justamente não se perca em seu caminho de escalada até si mesmo e, com isso, leve a termo o projeto de si que seu Selbst apresenta no horizonte de sua existência. No limite, o simesmo acima do indivíduo não é a ausência de uma identidade qualquer. Pelo contrário, é a reafirmação de uma filosofia da identidade, ainda que sob bases móveis e não essencializadas.

\section{Considerações finais}

Nas páginas precedentes, empreendi o esforço de evidenciar que a filosofia da educação do jovem Nietzsche é perpassada pelo problema da relação entre ipseidade e alteridade; em outras palavras do si-mesmo e do outro. A partir do ponto de vista que defendi, a leitura mais coerente dos textos do pensador alemão sobre a educação seria aquela que reconhece o aspecto bipartido de ambos esses conceitos. A alteridade é algo atua tanto dentro quanto fora do indivíduo e a ipseidade é algo que vale tanto no interior do indivíduo quanto acima dele. A verdadeira formação é algo possível somente a partir desse jogo complexo de tensões que constitui o indivíduo. Do mesmo modo, a identidade própria, o indivíduo bem logrado e, em última instância, o gênio só podem ser verdadeiramente atingidos, caso seja também atingido uma espécie de equilíbrio tenso entre o si-mesmo e o outro.

O ponto de vista defendido aqui aposta em uma interpretação do indivíduo e do si-mesmo nietzschiano que compreende que há no 
indivíduo algo de ineducável e imodelável, ou seja, algo que não é sujeito à processos educativos ou de aprendizagem, mas que é fundamental ao indivíduo. É certo que não se trata de essencializar o indivíduo, mas tampouco se trata de deixar de reconhecer certas características duradouras nele. Segundo essa interpretação, permanência ou duração não precisam estar necessariamente associadas às noções de essência e imutabilidade metafísicas. É possível pensar em um mundo que é todo e completamente vir-a-ser, mas que ao mesmo tempo porte em si duração. A meu ver, o conceito de si-mesmo em Nietzsche é atravessado por essa percepção: ele não é eternamente imutável, mas dura de tal modo que não é possível a um indivíduo modificá-lo radicalmente no decurso de uma vida. ${ }^{24}$ Dessa perspectiva, extraem-se algumas consequências para a interpretação do pensamento nietzschiano em geral, as quais apresento nos parágrafos seguintes.

A formação e transformação do indivíduo e da cultura no pensamento do jovem Nietzsche - em uma prefiguração do que se tornou mais explícito e desenvolvido mais tarde - não pode ser entendida como um processo sem jogos de dominação e organização de forças. Cada uma dessas forças podem ser entendidas ora como simesmo ora como outro, mas jamais deve-se perder de vista a importância dessas duas instâncias para a elevação da existência a outros patamares.

No que diz respeito ao papel da ipseidade e da alteridade na educação, não me parece que Nietzsche tenha promovido de fato alguma ruptura definitiva e absoluta entre suas produções de juventude

\footnotetext{
${ }^{24}$ Isso significa dizer que não é facultado ao ser humano transformar seu caráter ao longo de sua vida, ainda que o fundo "ineducável" seja passível de transformações ao longo de gerações. Nesse ponto, a interpretação que defendo está em contraposição a de outros importantes intérpretes do pensamento nietzschiano, como por exemplo, Dias (2011, pp. 100-113), que interpreta o aspecto "ineducável" do indivíduo como a incapacidade de transformar o caráter a partir de ações intencionais, racional ou moralmente determinadas. Para a pesquisadora, a formação e transformação do acontece antes no plano dos impulsos: através da mudança constante dos impulsos dominantes e da consequente escrita de um novo caráter de tempos em tempos no indivíduo forte.
} 
e seu período intermediário ou mesmo tardio. Por isso, no que diz respeito - especificamente - a esses elementos de sua filosofia, não podemos dar razão a Karl Schlechta, quando este pensa existir um rompimento mais radical entre os textos anteriores e posteriores a Humano, demasiado humano. ${ }^{25}$

De fato, não se pode dizer que há uma sintonia absoluta entre as obras de juventude de Nietzsche e as de períodos posteriores. O discurso não permaneceu inalterado. Naturalmente, ele se modulou e radicalizou em vários aspectos. Apesar de possuir uma razoável continuidade no plano geral da teoria da identidade pessoal, certas diferenças específicas tornam-se patentes na comparação entre períodos distintos. $\mathrm{O}$ aspecto antimetafísico da teoria da identidade pessoal tornou-se explícito a partir de Humano, demasiado humano (antes era implícito). $\mathrm{O}$ vocabulário de Nietzsche também se transformou com o passar do tempo. Passaram a ser cada vez mais presentes conceitos como "doença e saúde", "convalescênça", "nobre e escravo", "forças", "ressentimento", "má consciência".

Porém, vale sempre notar que tais produções de juventude, jamais foram de fato renegadas, senão em apenas alguns de seus aspectos (como a supervalorização de Wagner e Schopenhauer). No que se refere ao tema da identidade, como aqui se tentou fornecer indícios nesse sentido, deve-se admitir que houve a incorporação de novos pontos de vista e experiências na maturidade filosófica de Nietzsche. No entanto, deve-se igualmente admitir que não houve uma quebra absoluta entre as Extemporâneas e o restante da produção filosófica de Nietzsche.

É significativo observar o caso da Extemporânea sobre Schopenhauer. O panegírico direcionado à figura de Schopenhauer não apareceu em Ecce homo como um texto a ser descartado ou como um

\footnotetext{
${ }^{25}$ Esse importante comentador e editor das obras de Nietzsche na metade do século XX enxerga uma "unidade de espírito" nas obras posteriores a 1878, sem no entanto estender essa compreensão para as obras iniciais do pensamento nietzschiano (SCHLECHTA, 1997, pp. 13-46).
} 
erro de juventude. Longe de ser renegado, o texto foi na verdade reinterpretado à luz das próprias vivências mais tardias de Nietzsche. Em 1888, o autor nos advertiu que o texto não deveria mais ser lido como "Schopenhauer como educador", senão como "Nietzsche como educador" (EH/EH As Extemporâneas 3). Isto é, a obra de juventude passou a ser vista pelo pensador alemão como uma promessa a respeito de si mesmo, um discurso que, apesar de falar de Schopenhauer, significaria mais propriamente um vislumbre de como ele, Nietzsche, se tornaria (e se tornou) aquilo que ele é.

Por fim, vale observar que, para o jovem Nietzsche, educar e educar-se de modo elevado não são sinônimos de apresentar para si ou para o outro um caminho bem assentado e rigorosamente definido metodologicamente, visando garantir a obtenção de um conjunto de conhecimentos específicos sobre o mundo. Tampouco o fim da educação poderia ser reduzido à transmissão de técnicas de trabalho ou de produção, cujo propósito seria tornar alguém capaz de exercer o mais eficientemente possível uma ocupação profissional. Também não é sobre ser capaz de dizer com precisão e imediatamente "quem se é". A educação mais elevada tem, com efeito, a tarefa de fornecer uma relação frutífera e fortificadora entre a ipseidade e as alteridades $d o$, no e para além do indivíduo. Tudo precisa se passar de tal modo, que o encontro do outro e do si-mesmo seja criador de novos conhecimentos, de novas perspectivas e de novas verdades. Em vista desse caráter criador da educação mais elevada, é preciso que a educação assuma para si a necessidade de não saber aonde serão levados nesse processo aqueles que estão submetidos ao processo educacional. Em última instância, para se atingir patamares mais nobres, é preciso que o próprio indivíduo desconheça o que seu simesmo fará dele e de suas alteridades. 


\section{Referências}

AZEREDO, V. (2008). Nietzsche e a aurora de uma nova ética. São Paulo: Humanitas; Ijuí: Unijuí. https://doi.org/10.5007/16772954.2009v8n1p85

BROESE, K.; KOSSLER, M.; SALAQUARDA, B. (Hrsg.). (2007). Die Deutung der Welt: Jörg Salaquardas Schriften zu Arthur Schopenhauer. Würzburg: Königshausen \& Neumann.

DIAS, R. (2009). Amizade estelar: Schopenhauer, Wagner e Nietzsche. Rio de Janeiro: Imago.

DIAS, R. (2011). Nietzsche, vida como obra de arte. Rio de Janeiro: Civilização Brasileira.

GIACOIA JR, O. (2004). Sobre tornar-se o que se é. In: SALLES, João Carlos (Org.). Schopenhauer e o idealismo alemão. Salvador: Quarteto.

GIACOIA JR, O. (2012). Nietzsche $x$ Kant: uma disputa permanente a respeito de liberdade, autonomia e dever. Rio de Janeiro; São Paulo: Casa da palavra; Casa do saber.

ITAPARICA, A. (2004). Schopenhauer, Nietzsche e o ponto de vista do ideal. In: SALLES, J. C. (Org.). Schopenhauer \& o idealismo alemão. Salvador: Quarteto.

LAROSSA, J. (2009). Nietzsche \& a educação. Tradução de Semíramis Gorini da Veiga. 3. ed. Belo Horizonte: Autêntica.

LOPES, R. (2008). Ceticismo e vida contemplativa em Nietzsche. Tese de doutorado apresentada ao Departamento de Filosofia da UFMG.

MACHADO, R. (2002). Nietzsche e a verdade. 2. ed. Rio de Janeiro: Graal.

MARTON, S. (2000). Nietzsche: das forças cósmicas aos valores humanos. 2. ed. Belo Horizonte: Editora UFMG.

MÜLLER-LAUTER, W. (1997). A doutrina da vontade de poder em Nietzsche. Apresentação de Scarlett Marton e tradução de Oswaldo Giacoia Júnior. São Paulo: Annablume. 
MÜLLER-LAUTER, W. (2009). Nietzsche: sua filosofia dos antagonismos e os antagonismos de sua filosofia. Tradução de Clademir Araldi. São Paulo: Editora Unifesp.

NIETZSCHE, F. (1999). Sämtliche Werke: Kritische Studienausgabe in 15 Bänden. Edição organizada por G. Colli e M. Montinari. Berlim: Walter de Gruyter.

NIETZSCHE, F. (2003). Escritos sobre educação. Tradução, apresentação e notas de N. C. de M. Sobrinho. São Paulo: Loyola.

NIETZSCHE, F. (2003). Segunda consideração intempestiva: da utilidade e desvantagem da história para a vida. [Versão Kindle]. Tradução de Marco Antônio Casanova. Rio de Janeiro: Relume Dumará.

NIETZSCHE, F. (2007). Cinco prefácios para cinco livros não escritos. Tradução e prefácio de P. Süssekind. 4. ed. Rio de Janeiro: 7Letras.

NIETZSCHE, F. (2007). O nascimento da tragédia: ou helenismo e pessimismo. Tradução, notas e posfácio de J. Guinsburg. São Paulo: Companhia das Letras.

NIETZSCHE, F. (2007). Sobre verdade e mentira. Tradução de F. M. Barros. São Paulo: Hedra.

NIETZSCHE, F. (2008). Ecce homo: como alguém se torna o que é. Tradução, notas e posfácio de P. C. de Souza. São Paulo: Companhia das Letras.

NIETZSCHE, F. (2009). Wagner em Bayreuth: quarta consideração extemporânea. [Versão Kindle]. Tradução de Anna Hartmann Cavalcanti. Rio de Janeiro: Zahar.

NIETZSCHE, F. (2009-). Digitale Kritische Gesamtausgabe von Nietzsches Werken und Briefen. Edição organizada por Paolo D'Iorio, baseada na edição crítica de G. Colli e M. Montinari e publicada pela Nietzsche Source. Edição eletrônica. Recuperado de: http://www.nietzschesource.org/\#eKGWB. Acesso em: 23 mar. 2018.

NIETZSCHE, F. (2012). Sobre Schopenhauer. Revista Lampejo, vol. 1, n. 2, Fortaleza. 
SCHLECHTA, K. (1997). Le cas Nietzsche. Traduzido por André Cœuroy. Paris: Gallimard.

SCHOPENHAUER, A. (1977). Zürcher Ausgabe: Werke in zehn Bänden. Zürich: Diogenes.

SCHOPENHAUER, A. (2005). O mundo como vontade e como representação. Tomo I. Tradução de J. Barboza. São Paulo: Unesp.

SCHOPENHAUER, A. (2014). $O$ mundo como vontade $e$ representação. Tomo II. Volume 1. Tradução de E. R. da Fonseca. Curitiba: Editora UFPR.

SCHOPENHAUER, A. (2014). O mundo como vontade $e$ representação. Tomo II. Volume 2. Tradução de E. R. da Fonseca. Curitiba: Editora UFPR.

WEISSMANN, K. (1980). A vida de Schopenhauer. Belo Horizonte: Itatiaia.

Data de registro: 04/04/2018

Data de aceite: $24 / 04 / 2019$ 